\title{
A climatological study of the effect of sea-surface temperature on North Atlantic hurricane intensification
}

\author{
Erik Fraza* and James B. Elsner \\ Department of Geography, Florida State University, Tallahassee, FL, USA
}

(Received 14 January 2015; accepted 23 June 2015)

\begin{abstract}
The climatic influence of sea-surface temperature (SST) on intensification is examined for North Atlantic hurricanes by averaging hourly intensity increases from best-track data over the period 1986-2013 in $4^{\circ}$ by $4^{\circ}$ latitude-longitude grid cells. Independent monthly SST data over the same period are averaged in the same cells. After removing cells with cold water or fast moving hurricanes, the SST effect on intensification, at the climate scale, is quantified by regressing intensification onto SST while controlling for average intensity. The regression is performed using a generalized linear model from a gamma family and a logarithmic link function. The model shows a statistically significant relationship, with higher intensification values associated with higher SST values. On average, mean intensification increases by $16 \%[(9,20) \%$ uncertainty interval] for every $1{ }^{\circ} \mathrm{C}$ increase in mean SST. A clustered region where the model underpredicts intensification is noted over the southeastern Caribbean Sea, perhaps related to the fresh water plume from the Orinoco River.
\end{abstract}

Keywords: hurricane intensification; tropical cyclone; hurricane; sea-surface temperature; North Atlantic

\section{Introduction}

Hurricane intensity as measured by the maximum sustained near-surface wind speed is the subject of considerable academic and societal interest. For instance, what influence might climate change have on hurricane intensity? Webster, Holland, Curry, and Chang (2005) noted an upward trend in the occurrence of strong hurricanes worldwide, attributing it to climate change, and Elsner, Kossin, and Jagger (2008) found that the strongest hurricanes are becoming stronger with rising ocean temperature. Further, in introducing the Power Dissipation Index (PDI), Emanuel (2005) stated that hurricanes do not respond solely to sea-surface temperature (SST) changes. Other factors, such as vertical wind shear, affect a hurricane's intensity and PDI value. While research concerning the effect of SST on hurricane intensity is prevalent, most is concerned with specific storms.

Most research involving intensity change has been concerned with rapid intensification (herein RI). The National Hurricane Center (NHC) uses a $30 \mathrm{kt}$ per 24-h $\left(0.643 \mathrm{~m} \mathrm{~s}^{-1} \mathrm{~h}^{-1}\right)$ threshold to define a RI event (Kaplan \& DeMaria, 2003). A RI prediction model was introduced in 1993 to calculate the chance a storm would undergo RI at certain time intervals given four primary predictors: difference between current intensity and estimated maximum potential intensity given current SST, vertical shear

*Corresponding author. Email: ef10c@fsu.edu 
of the horizontal wind, persistence, and the flux convergence of eddy angular momentum at $200 \mathrm{mb}$ (Demaria \& Kaplan, 1994). The Statistical Hurricane Intensity Prediction Scheme (SHIPS) prediction model improved upon climatology and persistence, and was further improved upon in updates. SHIPS was then augmented with the release of the Rapid Intensification Index (RII) (Kaplan \& DeMaria, 2003). The RII was built upon SHIPS, and included 16 predictors in their model, including SST. However, an updated RII version began using oceanic heat content (OHC) data instead of SST data (Kaplan, DeMaria, \& Knaff, 2010). This updated RII index is the most skillful of all in predicting RI events, and is used by forecasters at the NHC.

Recent research has begun to also look at OHC, sometimes in place of SST in models. Oceanic upwelling within a hurricane brings up deeper waters, thus changing the SST (Mainelli, DeMaria, Shay, \& Goni, 2008; Shay, Goni, \& Black, 2000), whereas $\mathrm{OHC}$ is less affected by the upwelling. The slower the forward speed of the hurricane, the more upwelling will occur, further changing the original SST value (Lin, Pun, \& Wu, 2009). However, in situ OHC data is lacking (Shay \& Brewster, 2010), requiring usage of satellite data. This is often done using a blended version of radar altimetry and sea surface height anomaly data, which is then compared to hurricane season climatology to estimate the oceanic mixed layer depth. $\mathrm{OHC}$ is a beneficial variable for specific storms, but climatological studies involving hurricane intensity and intensity change use $\mathrm{OHC}$ about as often as SST.

In looking at the climatological effects of SST on intensity and intensity change, Cione and Uhlhorn (2003) showed how changes in SST are linked to changes in hurricane intensity and suggested a relationship between reduced inner-core ocean cooling and intensification. Yaukey (2014) investigated RI of hurricanes across the North Atlantic basin and found it most likely to occur in the Gulf of Mexico and the Caribbean Sea. Law and Hobgood (2007) developed statistical models for intensification using SST and vertical shear as explanatory variables. Balling and Cerveny (2006) looked at intensity change across the North Atlantic and found intensification rates higher in the western portion of the basin but no significant relationship to current or previous month's SST values. Strazzo, Elsner, Trepanier, and Emanuel (2013) analyzed the relationship of observed and simulated hurricane intensity to SST changes in the North Atlantic and found greater sensitivity across the western portion of the basin.

Missing is research examining the effect of SST on regional hurricane intensification rates. This study fills this void, building on the work presented by Fraza and Elsner (2014). Here, an hourly interpolated version of the hurricane database that provides intensification rates along the hurricane tracks is used (Elsner \& Jagger, 2013) to examine the influence of SST on intensification on the climate scale. The hourlyinterpolated values are averaged in grid cells across the North Atlantic using functions from the raster package (Hijmans, 2014) in the R programming language. Rectangular cells replace the hexagonal cells used by Fraza and Elsner (2014).

The paper is outlined as follows. The data and aggregation methods section describes the data and methods, including how intensification and SST are averaged spatially using a grid. The Intensification vs. sea-surface temperature models the relationship between intensification and SST, as well as examining the distribution of model residuals. The Discussion section looks more closely at the cluster of positive residuals in the eastern Caribbean Sea, and the Summary and conclusions section provides a summary and a list of conclusions. The goal of this work is a better understanding of intensification leading to improvements in real-time forecasts of intensity (Cione, Kalina, Zhang, \& Uhlhorn, 2013; DeMaria, Knaff, \& Sampson, 2007; Rappaport et al., 2009). 


\section{Data and aggregation methods}

\section{Hourly intensity change}

The hurricane data used in this study are derived from HURDAT (Jarvinen, Neumann, \& Davis, 1984). HURDAT contains the most comprehensive set of information on past North Atlantic tropical cyclones. The information is from post-season analyses done on the available data by meteorologists at the National Oceanic and Atmospheric Administration (NOAA) NHC. HURDAT includes estimates of the hurricane's center position and intensity. The center position is given in geographic coordinates (latitude and longitude) to a precision of a tenth of a degree. Intensity is the 1-min near-surface wind speed $(\sim 10 \mathrm{~m})$ given in knots $\left(1 \mathrm{kt}=0.5144 \mathrm{~m} \mathrm{~s}^{-1}\right)$ to a precision of $5 \mathrm{kt}$. Values are provided in 6-h intervals, starting at 00 UTC (Universal Time Coordinate).

This study uses the data over the period 1986 through 2013. The start year is based on the year the Enhanced Infrared method (EIR) of the Dvorak technique became operational (Knaff, Brown, Courtney, Gallina, \& Beven, 2010). Fraza and Elsner (2014) noted a decrease in the HURDAT data quality associated with intensity prior to 1986. The implementation of the EIR method of the Dvorak Technique at the NHC eliminated data biases from forecasters using different techniques. The EIR method provides an objective estimate of tropical cyclone intensity from satellite imagery (Dvorak, 1984). Only tropical cyclones above hurricane intensity $\left(33 \mathrm{~m} \mathrm{~s}^{-1}\right)$ are included. The raw HURDAT positions (center fixes), intensities, and intensity changes were interpolated to 1-h intervals using a Savitzky-Golay smoothing and a cubic polynomial algorithm by Elsner and Jagger (2013) (available from http://myweb.fsu. edu/jelsner/data/best.interp.zip). This is done because the 6 -h values can be too coarse for spatial analysis and modeling. The 6-h values from HURDAT are preserved in the hourly-interpolated data. The smoothing allows for derivative calculations with low-order of error. Here, the derivative of interest is the hourly intensity change in units of $\mathrm{m} \mathrm{s}^{-1}$ per hour. Only center fixes over water are considered.

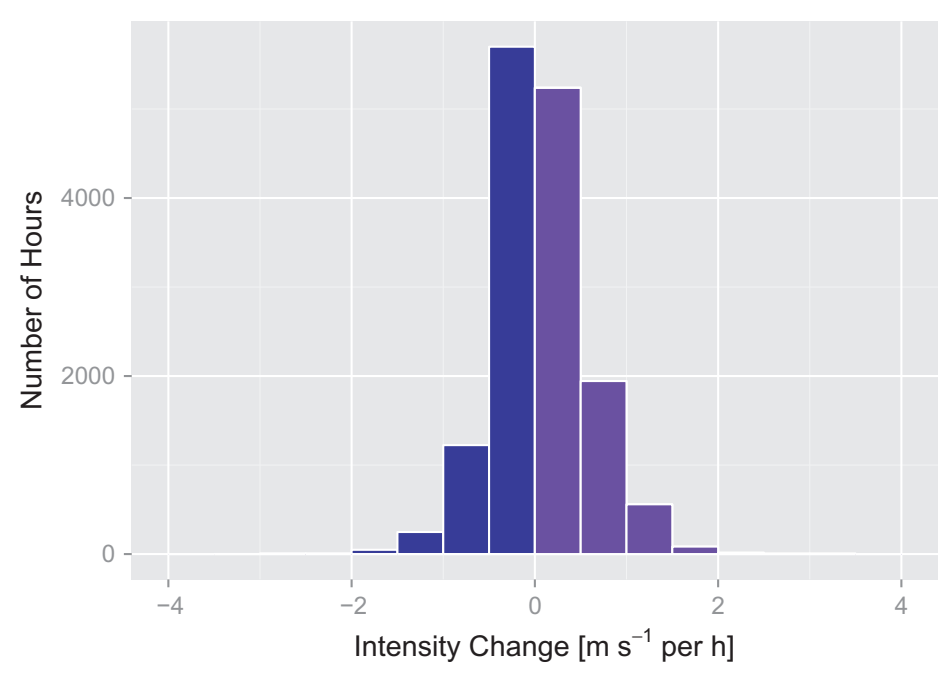

Figure 1. Histogram of hourly hurricane intensity change for the months June-October over the period 1986-2013. 
There are 14,310 hourly intensity change values from 173 hurricanes over the 28 -year period. The mean intensity change is $+0.059 \mathrm{~m} \mathrm{~s}^{-1} \mathrm{~h}^{-1}$, with a range between -2.92 and $+3.16 \mathrm{~m} \mathrm{~s}^{-1} \mathrm{~h}^{-1}$ (Figure 1). The distribution is symmetric about zero, indicating nearly as many hours of weakening as hours of strengthening, but it is more peaked (greater kurtosis) than a Gaussian distribution. This study focuses exclusively on intensification (purple portion of the histogram). There are 7407 hourly intensification values for hurricanes over water. The median intensification is $0.343[0.141,0.610]$ $\mathrm{m} \mathrm{s}^{-1} \mathrm{~h}^{-1}$ [1st and 3rd quartiles] or $16[6.6,28.5]$ knots per day.

\section{Mean intensification by grid cell}

The main idea of this paper is to quantify the relationship between SST and hurricane intensification on the climate scale. This is done by creating a $4^{\circ}$ latitude-longitude grid extending from 10 to $50^{\circ} \mathrm{N}$ latitude and from 20 to $100^{\circ} \mathrm{W}$ longitude. The grid is defined using functions in the raster package (Hijmans, 2014). Intensification and SST values are averaged in each grid cell.

The average intensification is over all intensifying hours for over-ocean hurricanes within the cell for the months June-October (Figure 2). November storms are removed from the analysis to avoid possible detrimental late-season effects. Some cells have more than one hurricane, as is the case with Ivan and Dean south of Jamaica. In this case the average is over all hours for both hurricanes. Track portions without cells indicate either the cyclone is weaker than a hurricane or it is weakening.

Aggregation is done over all 173 hurricanes for the portion of the tracks that are intensifying (Figure 3(a)). The domain contains 130 cells with at least one hour of an intensifying hurricane. Average values range from a minimum near zero to a maximum of $1.11 \mathrm{~m} \mathrm{~s}^{-1} \mathrm{~h}^{-1}$. Highest intensification occurs in cells across the Caribbean Sea and Gulf of Mexico. Lower values are noted in cells farther north. The coefficient of variation, defined as the ratio of the standard deviation to the mean, is generally less than unity across the basin, with the exception of several cells in the north (Figure 3(b)). Four cells have only a single hour of intensification, so no coefficient of variation is computed.

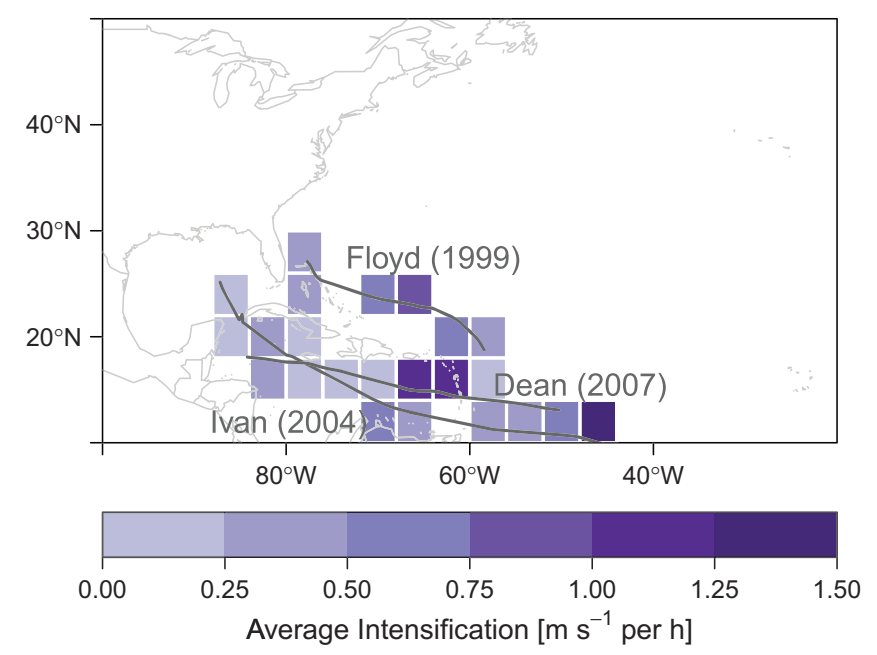

Figure 2. Tracks and average intensification per grid cell for three hurricanes. 

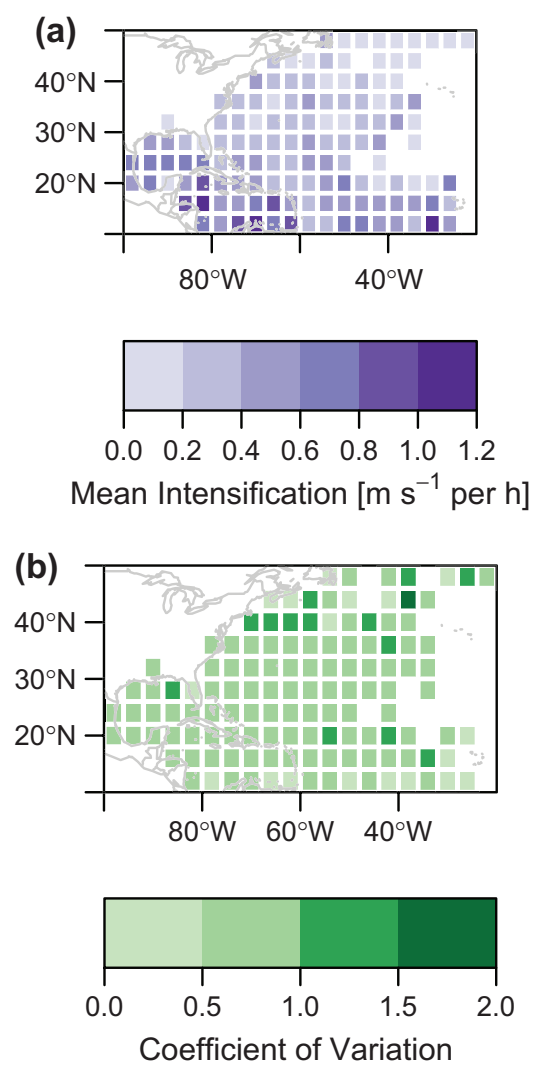

Figure 3. Hurricane intensification per grid cell. (a) Mean intensification for intensifying hurricanes and (b) coefficient of variation in intensification. Four cells have only a single hour of intensification, so no coefficient of variation is computed.

\section{Mean sea surface temperature by grid cell}

The SST data used in this study are the NOAA Extended Reconstructed Sea Surface Temperature V3b. The data are monthly averages on a $2^{\circ}$ by $2^{\circ}$ grid. Additional information about these data are found at http:/www.esrl.noaa.gov/psd/data/gridded/data.noaa.ersst. html. The June-October SST values are averaged over the period 1986-2013 within each intensification cell (Figure 4). Because of the coarse spatial resolution of the SST data, four intensification cells near the coast are without SST values.

The mean SST values over the 126 cells range from a low of $9.1^{\circ} \mathrm{C}$ to a high of $29.3^{\circ} \mathrm{C}$. Cells with the highest SST values occur across the Caribbean Sea and Gulf of Mexico, with lower values farther north.

\section{Warm ocean and slow moving hurricanes}

Interest centers on SST as a factor in statistically explaining the variation in intensification on the climate scale. Other factors are important. Hurricanes sometimes intensify as a result of interaction with high-altitude middle latitude troughs (e.g. DeMaria, Kaplan, \& Baik, 1993; Hanley, Molinari, \& Keyser, 2001). The increase in a hurricane's forward speed as it moves northward into high latitudes can also result in 


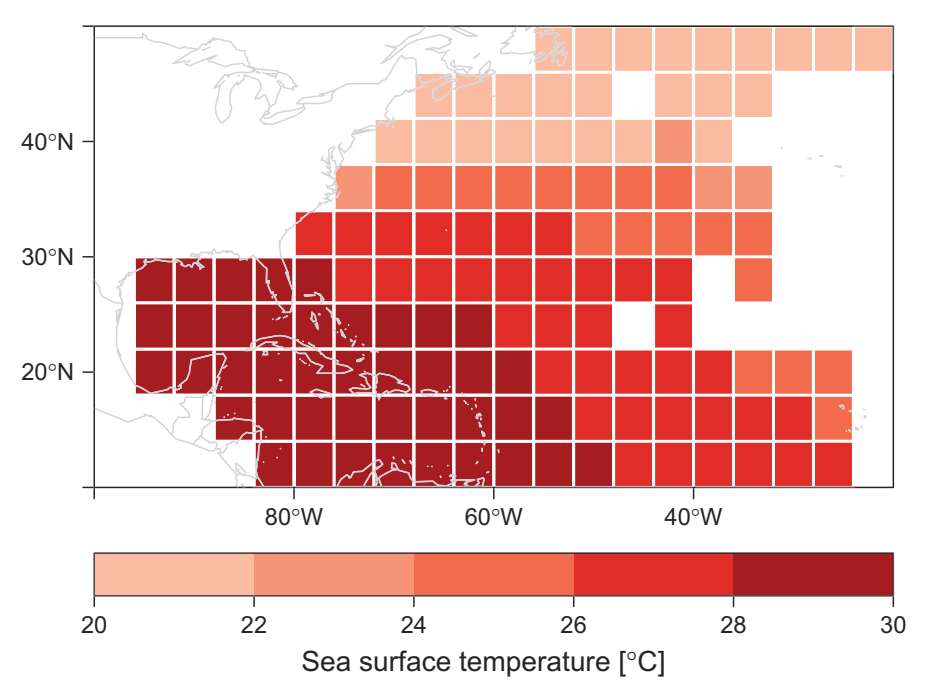

Figure 4. Mean sea-surface temperature per grid cell. Cells with SST values below $20^{\circ} \mathrm{C}$ are color-coded using the lowest temperature interval.

intensification (e.g. Jones et al., 2003). To control for these two factors, cells where the mean SST is below $22{ }^{\circ} \mathrm{C}$ and where averaged forward speeds are higher than $10 \mathrm{~m} \mathrm{~s}^{-1}$ were eliminated. The mean forward speed of hurricanes in the 'warm' cells $\left(\geq 22{ }^{\circ} \mathrm{C}\right)$ was $6.0 \mathrm{~m} \mathrm{~s}^{-1}$. This compares with a mean forward speed of $17.8 \mathrm{~m} \mathrm{~s}^{-1}$ for hurricanes in the 'cold' cells $\left(<22^{\circ} \mathrm{C}\right)$. Cells east of $32^{\circ} \mathrm{W}$ longitude were eliminated because of the greater uncertainty in intensity estimates for hurricanes this far east.

The above criteria result in a grid that extends from $10^{\circ}$ to $38^{\circ} \mathrm{N}$ latitude and from $96^{\circ}$ to $32^{\circ} \mathrm{W}$ longitude. It covers the main hurricane development region of the North Atlantic basin, extending westward through the Caribbean Sea and the Gulf of Mexico and northward across the central subtropical Atlantic. The reduced grid removes the large spatial variation in intensification but eliminates cells with relatively large coefficient-of-variation values. Only the 94 cells over the grid having intensification and SST data are used in the modeling (Figure 5).

\section{Intensification vs. sea-surface temperature}

The mean intensification over the domain is $0.419 \mathrm{~m} \mathrm{~s}^{-1} \mathrm{~h}^{-1}$ with an inter-quartile range of $[0.297,0.541] \mathrm{m} \mathrm{s}^{-1} \mathrm{~h}^{-1}$. This translates to a mean and inter-quartile range of $19.6[13.8,25.2] \mathrm{kt} \mathrm{d}^{-1}$. The highest mean intensification is $50.8 \mathrm{kt} \mathrm{d}^{-1}$. The NHC uses a threshold of $30 \mathrm{kt} \mathrm{d}^{-1}\left(0.643 \mathrm{~m} \mathrm{~s}^{-1} \mathrm{~h}^{-1}\right)$ to define 'RI.' The mean SST over the domain is $27.4{ }^{\circ} \mathrm{C}$, with an inter-quartile range of $[26.3,28.6]{ }^{\circ} \mathrm{C}$. The warmest cell has a mean SST of $29.3{ }^{\circ} \mathrm{C}$, and the coldest cell a mean SST of $23.4{ }^{\circ} \mathrm{C}$, a difference of about $6{ }^{\circ} \mathrm{C}$. Neighboring cells tend to have similar intensification values, and the spatial correlation computed using Moran's I definition is 0.418 , with a variance of 0.003 .

A regression model is fit to the cell-averaged intensification and SST values to quantify the relationship between these two variables. Because intensification is strictly positive, having a distribution that is skewed to the right (see Figure 6), it is regressed onto average SST using a generalized linear model from a gamma family with a logarithmic link function. Specifically, the model is given by 


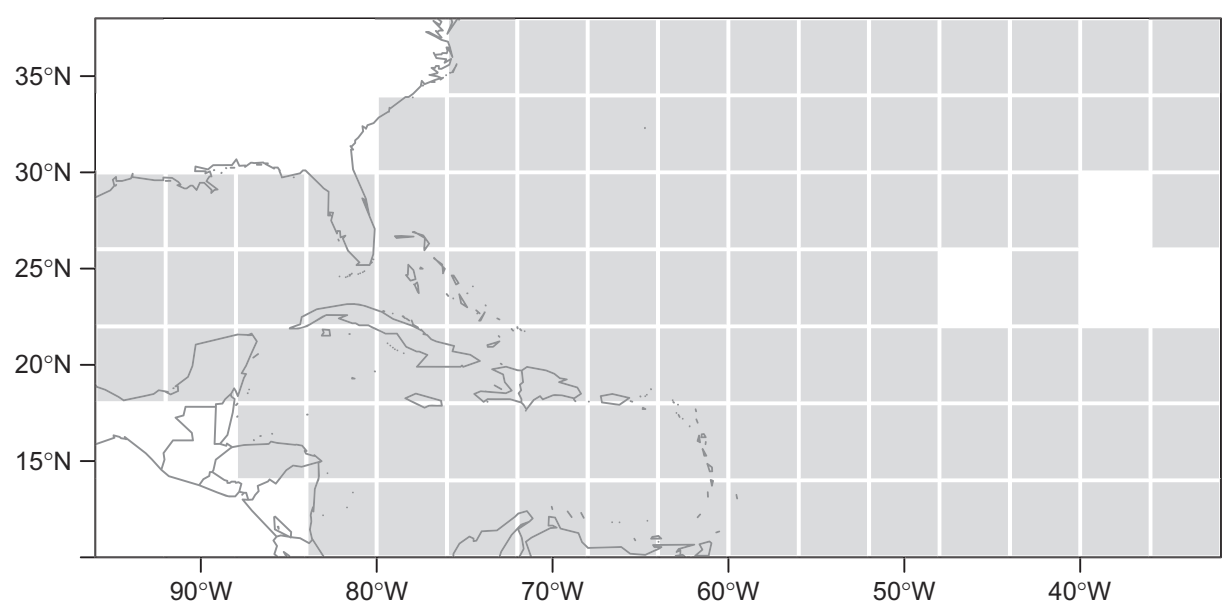

Figure 5. Cells used to model the relationship between hurricane intensification and SST.

$$
\log \left(\hat{a}_{i}\right)=\beta_{o}+\beta_{\mathrm{SST}} \cdot \mathrm{SST}_{i}+\beta_{W} \cdot W_{i}
$$

where $\hat{a}_{i}, \mathrm{SST}_{i}$, and $W_{i}$ are the predicted mean intensification (acceleration units), SST, and intensity in cell $i$, respectively, and the $\beta$ 's are regression coefficients. Intensity is included as a predictor since intensification tends to be higher at some point during its lifetime for storms with higher than average intensity. Studies such as those by Kaplan

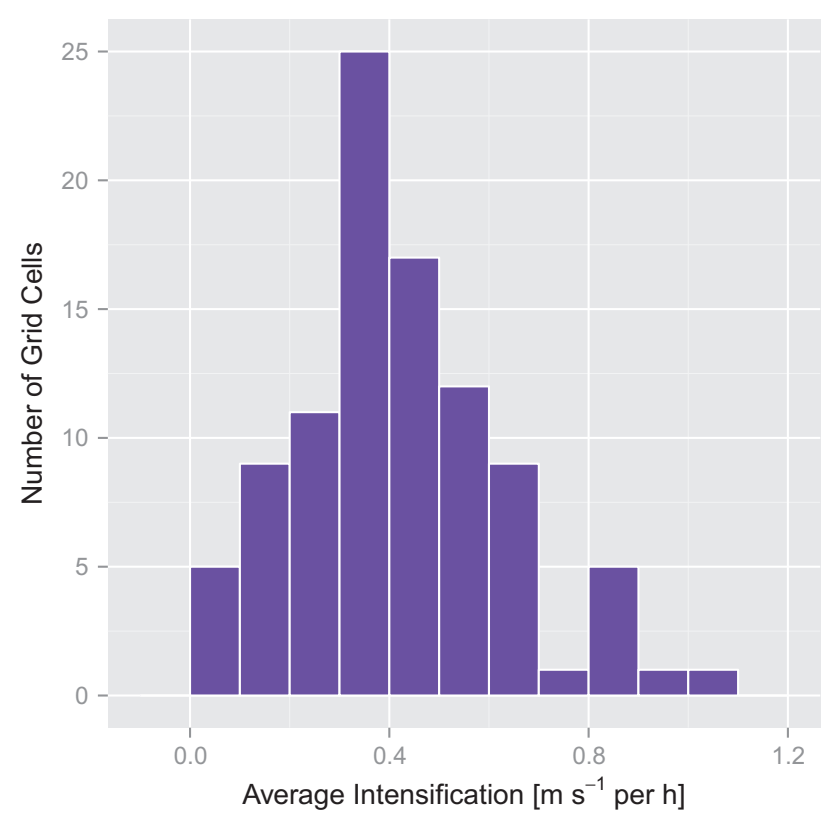

Figure 6. Histogram of mean intensification. The mean values are taken from the cells shown in Figure 5. 
et al. (2010) and Elsberry, Lambert, and Boothe (2007) have noted that many of the strongest hurricanes in the North Atlantic basin have undergone RI at some point during their lifetimes. We find the model with intensity as a covariate gives a better fit to the data than the model without it, as indicated by Akiake Information Criterion. The difference between the mean intensification and the intensification predicted by the model is the residual $\left(\varepsilon_{i}\right)$.

The model indicates a significant relationship with $\mathrm{SST}$ ( $p$-value on $\beta_{\mathrm{SST}}$ is less than 0.001 ) after controlling for intensity, with higher intensification values associated with higher SST values (Figure 7). The SST coefficient shows intensification increasing by $15.5 \%[(\exp (0.144)-1) 100 \%]$ for every $1{ }^{\circ} \mathrm{C}$ increase in SST holding intensity constant. The $95 \%$ confidence interval (uncertainty interval - UI) on that percentage is $[8.5 \%, 20.2 \%]$. Model residuals (Figure 8) vary from -0.417 to $+0.619 \mathrm{~m} \mathrm{~s}^{-1} \mathrm{~h}^{-1}$ with a median of $-0.019 \mathrm{~m} \mathrm{~s}^{-1} \mathrm{~h}^{-1}$.

Positive residuals indicate the model underpredicts intensification for a given value of SST and intensity. Regions with a preponderance of positive residuals include the central tropical Atlantic and much of the Caribbean Sea (Figure 9). Negative residuals indicate the model overpredicts intensification. Cells with largest negative residuals are found over the Florida and Yucatan peninsulas. This makes sense, as the adjacent waters are warm enough to support RI but proximity to land keeps average intensification rates in check.

Overall, there is no significant spatial autocorrelation $(I=0.041)$ in the model residuals, obviating the need to entertain a spatial regression model. Locally, however, there is a cluster of positive residuals in the eastern Caribbean Sea. The spatial pattern

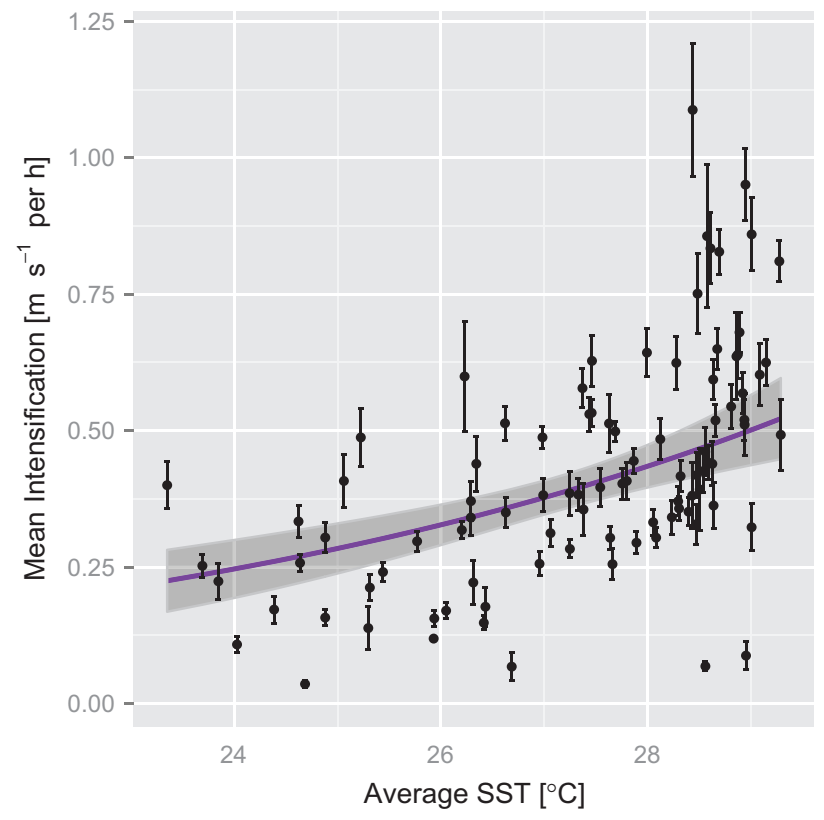

Figure 7. Intensification vs. sea-surface temperature (SST). Points are the per-cell mean intensification and vertical lines are the margins of error (one standard error). The gamma regression line, holding intensity constant at a mean value, is shown in purple, and the $95 \%$ uncertainty band is shown in gray. 

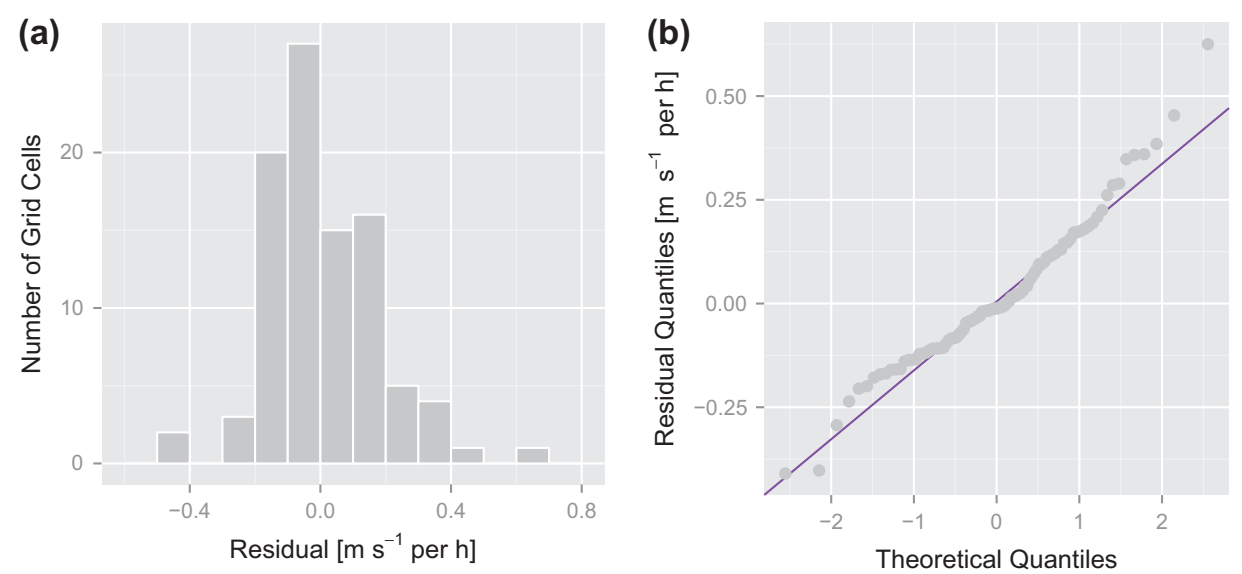

Figure 8. Model residuals: (a) distribution and (b) quantile-normal plot.

suggests that the relationship between intensification and SST is relatively stronger over this region compared to elsewhere. A map of the residual spatial correlation clearly identifies this area of large residuals as a region of high correlation (Figure 10). The correlation is computed using local Moran's I (Anselin, 1995), with the local neighborhood defined as the eight contiguous cells (queen's case). The equation is given as

$$
I_{i}=\frac{N \varepsilon_{i}}{{ }_{i} \varepsilon_{i j}^{2}} w_{i j} \varepsilon_{j},
$$

where $\varepsilon_{i}$ is the residual in cell $i, N$ is the number of cells, and $w_{i, j}$ is a $3 \times 3$ matrix of 1 's. Spatial correlation values are generally between \pm 1 across the North Atlantic, with the exception of cells over the Caribbean.

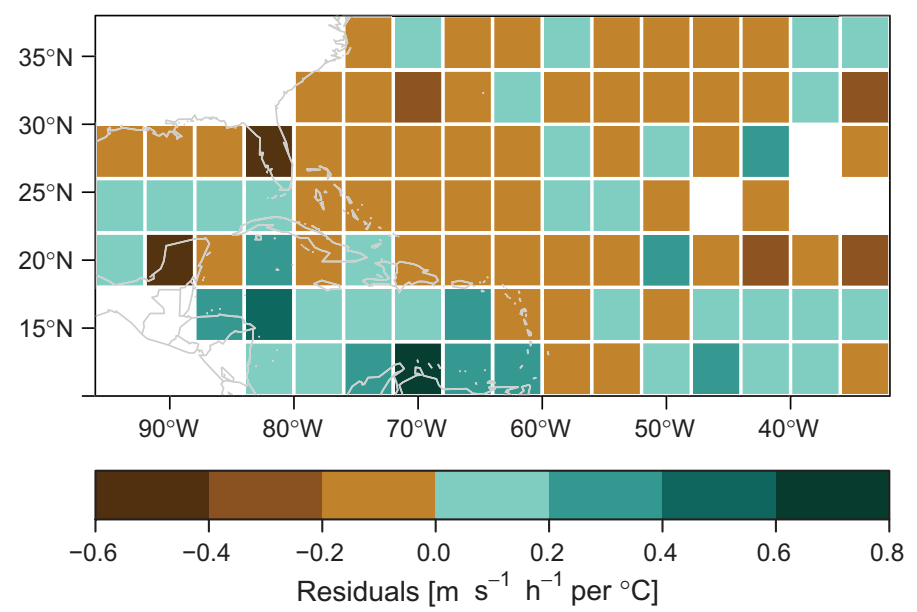

Figure 9. Residuals from a regression model of intensification onto SST and intensity. The residuals are the difference between the mean intensification and the predicted intensification in each cell. 


\section{Discussion}

Vertical shear of the environmental flow can affect the thermal structure of a hurricane and limit intensification through differential advection of potential vorticity ( $\mathrm{Wu} \&$ Emanuel, 1993). DeMaria (1996) suggests that low-latitude tropical cyclones tend to be particularly sensitive to the effects of shear. Atmospheric dryness has also been shown to limit intensification by displacing latent heating outward from the center of circulation (Braun, Sippel, \& Nolan, 2012; Hendricks, Peng, Fu, \& Li, 2010).

But the cluster of positive residuals over the southern Caribbean Sea is the result of strong hurricanes in this region, including Joan in 1988 as a category 4 hurricane and Ivan in 2004, Emily in 2005, and Felix in 2007 as category 5 hurricanes. Underprediction of the model in this region implies greater sensitivity of intensification to SST, suggesting less sensitivity to the effects of shear. The greater sensitivity could be the result of greater mid-level relative humidity or the result of fresh water fluxes from the Gulf of Venezuela and the Orinoco River.

The idea of fresh water plume from the Orinoco River affecting intensification rates is discussed by Ffield (2007). Fresh water dilutes the saltier sea water, causing the water column to become more buoyant and stable, thus allowing greater warming of the water column. The warmer column is less susceptible to cooling from mixing due to strong hurricane winds, making this region more sensitive to SST than elsewhere in the basin.

To examine this hypothesis, monthly mean salinity data on a $1^{\circ}$ latitude-longitude grid are obtained from NOAA's National Oceanographic Data Center (NODC) World Ocean Atlas (WOA) data-set (Figure 11). The data are split into early season (June-August) and late season (September-October) for the years 1986 through 2008 and are averaged within the same cells. Further, the corresponding SSTs are also displayed. The SST values are interpolated in order to be displayed on the smaller grid. Lower salinity values shift northward and slightly west into the eastern portion of the Caribbean Sea in the late season (Figure 11(c)). Further, warmer SSTs are more prevalent during the late season (Figure 11(d)). The warmest waters are found in and around the lowest salinity values in the region, further indicating a possible relationship. Finally, the relationships

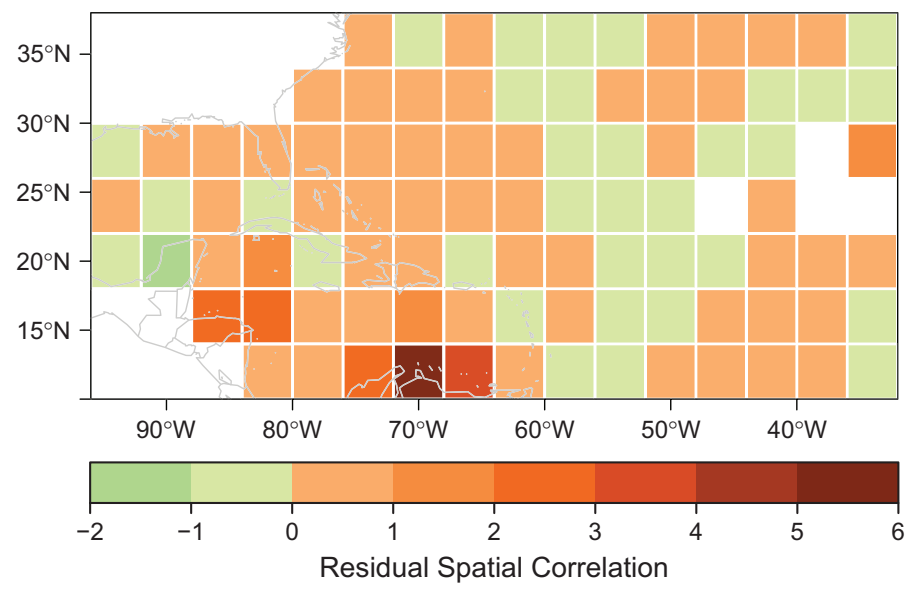

Figure 10. Spatial correlation of the residuals from a regression model of intensification onto SST and intensity. 


\section{(a)}
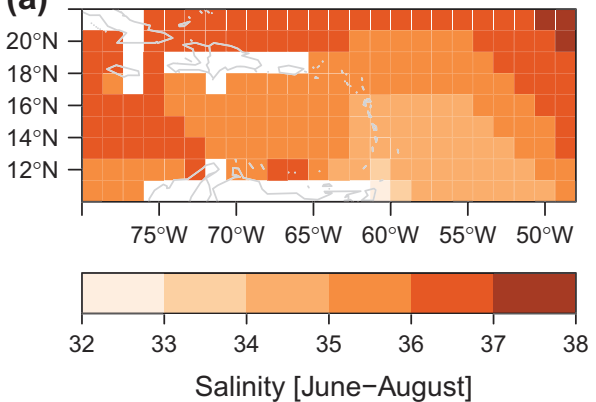

(c)
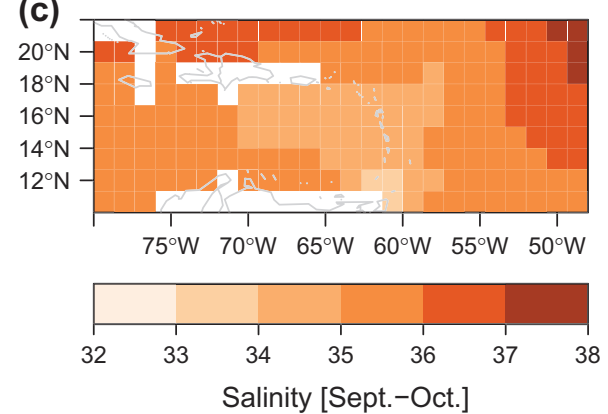

(b)

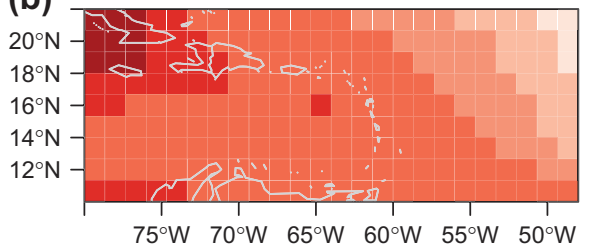

$75^{\circ} \mathrm{W} \quad 70^{\circ} \mathrm{W} \quad 65^{\circ} \mathrm{W} \quad 60^{\circ} \mathrm{W} \quad 55^{\circ} \mathrm{W} \quad 50^{\circ} \mathrm{W}$

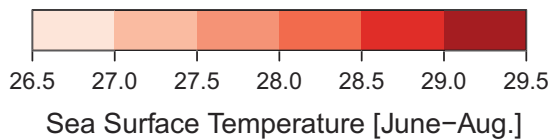

(d)

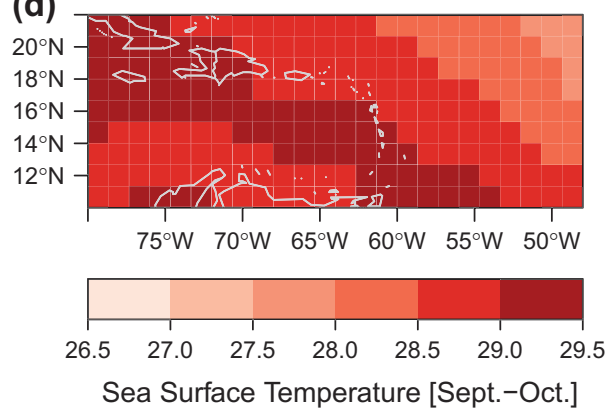

Figure 11. Mean salinity and mean SST. Average per cell for the months (a) June-August and (b) September-October. The salinity data are over the time period 1986-2008 and the SST data are over the time period 1986-2013. The corresponding SSTs are given in panels (c) and (d), respectively.

between average salinity and intensification residuals are also compared. The correlation coefficient between the average salinity and the intensification residuals is -0.18 ( $[-0.37$, $0.03] 95 \%$ UI). While small and only marginally significant, the correlation is consistent with the hypothesis of Ffield (2007) that salinity is playing a role in hurricane intensification of storms in this region.

\section{Summary and conclusions}

By averaging intensity increases and SST data in cells on a $4^{\circ}$ latitude-longitude grid, the climatic effect of SST on intensification is examined for North Atlantic hurricanes. The effect is quantified by regressing the intensification values onto the SST values. The regression uses a generalized linear model from a gamma family with a logarithmic link function.

The distribution of mean intensification of hurricanes, coefficient of variation, and mean SST over the period 1986-2013 are mapped across the cells. While larger intensification rates are found across the southern part of the basin, regions of highest intensification are found primarily in the Caribbean Sea and Gulf of Mexico. Coefficient of determination values are mostly low, with the exception of those for the extreme northern part of the basin. The highest SST values are found in the southwestern part of the basin.

To better account for effects on intensification, cells with mean SST. below $22{ }^{\circ} \mathrm{C}$ or averaged forward speeds higher than $10 \mathrm{~m} \mathrm{~s}^{-1}$ are eliminated. With the remaining 
data being positively skewed, a generalized linear model from a gamma family with a logarithmic link function is used to regress intensification onto SST, holding intensity constant. A significant relationship is found, with intensification increasing by $15.5 \%$ for every $1{ }^{\circ} \mathrm{C}$ increase in SST.

Most areas have relatively small model residuals, but there is a cluster of high positive values in the southern Caribbean Sea, suggesting a stronger relationship between intensification and SST in this area. The cluster is consistent with the hypothesis that the low salinity plume from the Orinoco River makes this region less susceptible to vertical mixing, thereby keeping the ocean relatively warm in the presence of strong hurricane winds. Additional studies are needed to better articulate the role salinity plays in modulating intensification rates across the North Atlantic.

A limitation in this study is that factors besides salinity affect the hurricane intensification rate in the Southern Caribbean Sea. These other factors could include increased vorticity to go along with some combination of decreased vertical wind shear, increased mid-level relative humidity, and decreased salinity. Further, aside from salinity, these factors are likely associated with other geographic areas with positive residuals, including the eastern portion of the main development region.

Additional studies are needed to better articulate the role salinity plays in modulating intensification rates across the North Atlantic. We also plan to investigate the role of $\mathrm{OHC}$ in both standard salinity and reduced salinity environments in the future.

\section{Acknowledgments}

Partial financial support for this research came from Climatek. The analysis and modeling were performed using the open-source $\mathrm{R}$ package for statistical computing. The codes used to produce the figures in this paper are available from http://myweb.fsu.edu/jelsner/Intensification.html.

\section{Disclosure statement}

No potential conflict of interest was reported by the authors.

\section{References}

Anselin, L. (1995). Local indicators of spatial association - LISA. Geographical Analysis, 27, 93-115.

Balling, R. C. J., \& Cerveny, R. S. (2006). Analysis of tropical cyclone intensification trends and variability in the North Atlantic basin over the period 1970-2003. Meteorology and Atmospheric Physics, 93, 45-51. doi:10.1007/s00703-006-0196-5

Braun, S. A., Sippel, J. A., \& Nolan, D. S. (2012). The impact of dry midlevel air on hurricane intensity in idealized simulations with no mean flow. Journal of the Atmospheric Sciences, 69, 236-257.

Cione, J., Kalina, E., Zhang, J., \& Uhlhorn, E. (2013). Observations of air-sea interaction and intensity change in hurricanes. Monthly Weather Review, 141, 2368-2382.

Cione, J. J., \& Uhlhorn, E. W. (2003). Sea surface temperature variability in hurricanes: Implications with respect to intensity change. Monthly Weather Review, 131, 1783-1796.

DeMaria, M. (1996). The effect of vertical shear on tropical cyclone intensity change. Journal of the Atmospheric Sciences, 53, 2076-2088.

Demaria, M., \& Kaplan, J. (1994). Sea surface temperature and the maximum intensity of Atlantic tropical cyclones. Journal of Climate, 7, 1324-1334.

DeMaria, M., Kaplan, J., Baik, J.-J. (1993). Upper-level eddy angular momentum fluxes and tropical cyclone intensity change. Journal of the Atmospheric Sciences, 50, 1133-1147.

DeMaria, M., Knaff, J., \& Sampson, C. (2007). Evaluation of long-term trends in tropical cyclone intensity forecasts. Meteorology and Atmospheric Physics, 97, 19-28. 
Dvorak, V. F. (1984). Tropical cyclone intensity analysis using satellite data (Vol. 11; Technical Report.). Miami, FL: NOAA NWS NHC.

Elsberry, R. L., Lambert, T. D. B., \& Boothe, M. A. (2007). Accuracy of Atlantic and eastern North Pacific tropical cyclone intensity forecast guidance. Weather and Forecasting, 22, 747-762.

Elsner, J., \& Jagger, T. (2013). Hurricane climatology: A modern statistical guide using $R$. New York, NY: Oxford University Press.

Elsner, J. B., Kossin, J. P., \& Jagger, T. H. (2008). The increasing intensity of the strongest tropical cyclones. Nature, 455, 92-95. doi:10.1038/nature 07234

Emanuel, K. (2005). Increasing destructiveness of tropical cyclones over the past 30 years. Nature, 436, 686-688.

Ffield, A. (2007). Amazon and Orinoco River plumes and NBC rings: Bystanders or participants in hurricane events? Journal of Climate, 20, 316-333.

Fraza, E., \& Elsner, J. (2014). A spatial climatology of North Atlantic hurricane intensity change. International Journal of Climatology, 34, 2918-2924. doi:10.1002/joc.3884

Hanley, D., Molinari, J., \& Keyser, D. (2001). A composite study of the interactions between tropical cyclones and upper-tropospheric troughs. Monthly Weather Review, 129, 2570-2584.

Hendricks, E. A., Peng, M. S., Fu, B., \& Li, T. (2010). Quantifying environmental control on tropical cyclone intensity change. Monthly Weather Review, 138, 3243-3271.

Hijmans, R. J. (2014). raster: Geographic data analysis and modeling [Computer software manual]. Retrieved from http://CRAN.R-project.org/package=raster (R package version 2.2-12)

Jarvinen, B. R., Neumann, C. J., \& Davis, M. A. S. (1984). A tropical cyclone data tape for the North Atlantic basin, 1886-1983: Contents, limitations, and uses (Technical Memo. No. 22). Miami, FL: NOAA NWS NHC.

Jones, S. C., Harr, P. A., Abraham, J., Bosart, L. F., Bowyer, P. J., Evans, J. L., ... Thorncroft, C. (2003). The extratropical transition of tropical cyclones: Forecast challenges, current understanding, and future directions. Weather and Forecasting, 18, 1052-1092.

Kaplan, J., \& DeMaria, M. (2003). Large-scale characteristics of rapidly intensifying tropical cyclones in the North Atlantic basin. Weather and Forecasting, 18, 1093-1108.

Kaplan, J., DeMaria, M., \& Knaff, J. A. (2010). A revised tropical cyclone rapid intensification index for the Atlantic and eastern North Pacific basins. Weather and Forecasting, 25, 220-241.

Knaff, J., Brown, D., Courtney, J., Gallina, G., \& Beven, J., II. (2010). An evaluation of Dvorak technique-based tropical cyclone intensity estimates. Weather and Forecasting, 25, 1362-1379.

Law, K. T., Hobgood, J. S. (2007). A statistical model to forecast short-term Atlantic hurricane intensity. Weather and Forecasting, 22, 967-980.

Lin, I., Pun, I.-F., \& Wu, C.-C. (2009). Upper-ocean thermal structure and the western North Pacific category 5 typhoons. Part II: Dependence on translation speed. Monthly Weather Review, 137, 3744-3757.

Mainelli, M., DeMaria, M., Shay, L. K., \& Goni, G. (2008). Application of oceanic heat content estimation to operational forecasting of recent Atlantic category 5 hurricanes. Weather and Forecasting, 23, 3-16.

Rappaport, E., Franklin, J., Avila, L., Baig, S., II, Beven, J., Blake, E., ... Tribble, A. (2009). Advances and challenges at the national hurricane center. Weather and Forecasting, 24, 395-419.

Shay, L. K., Brewster, J. K. (2010). Oceanic heat content variability in the Eastern Pacific ocean for hurricane intensity forecasting. Monthly Weather Review, 138, 2110-2131.

Shay, L., Goni, G., Black, P. (2000). Effects of a warm oceanic feature on Hurricane Opal. Monthly Weather Review, 128, 1366-1383.

Strazzo, S., Elsner, J. B., Trepanier, J. C., \& Emanuel, K. A. (2013). Frequency, intensity, and sensitivity to sea surface temperature of North Atlantic tropical cyclones in best-track and simulated data. Journal of Advances in Modeling Earth Systems, 5, 500-509.

Webster, P. J., Holland, G. J., Curry, J. A., Chang, H. R. (2005). Changes in tropical cyclone number, duration, and intensity in a warming environment. Science, 309, 1844-1846. doi:10.1126/science. 1116448

Wu, C.-C., \& Emanuel, K. A. (1993). Interaction of a baroclinic vortex with background shear: Application to hurricane movement. Journal of the Atmospheric Sciences, 50, 62-76.

Yaukey, P. (2014). Intensification and rapid intensification of North Atlantic tropical cyclones: Geography, time of year, age since genesis, and storm characteristics. International Journal of Climatology, 34, 1039-1049. doi:10.1002/joc.3744 